examination. When I wrote my paper for the Royal Society, I had altogether forgotten this circumstance, which I much regret; a copy of the paper itself had been carefully laid aside by me for reference, and suffered the fate of most such papers. ${ }^{1}$ Having, however, now referred to this document, I will put it in evidence on the question now discussed, and the reader will hear what Prof. Sollas has had to say. The author examined five of my slides of chertsections under the microscope, and states as the result of his examination; " in the first place, to completely confirm his (Prof. Hull's) clear descriptions of the appearances presented by them (the chertsections) ; and next, to establish the truth of my supposed detection of sponge-spicules," as shown in the plate accompanying my original paper. This is very valuable testimony.

As to the question of the geological position of the so-called "Yoredale Series," I have only to say that I have used the term as it is understood on the Geological Survey throughout the wide district where, in conjunction with some of my colleagues, I mapped these beds some years ago in South Lancashire, Cheshire, Derbyshire, and the adjoining parts of Yorkshire, an area of not less than 2000 square miles. What may be the exact relations of these beds to those of the Valley of the Yore as described by Phillips, I am not prepared to say. It is well known that the Lower and Middle Carboniferous strata undergo considerable alteration both in character and thickness as we proceed northwards from Derbyshire and Cheshire; and I can only now refer Dr. Hinde to my paper on the Classification of the Carboniferous Rocks published in the Quarterly Journal of the Geological Society, vol. xxxiii. for my views on this subject.

In conclusion, I have to add, that if I have misquoted Dr. Hinde, as he aftirms, I can only express regret, as I took special care not to do so, as will be seen by referring to my paper in the Proc. Roy. Soc. vol. xlii. p. 305. My late valued colleague, Mr. Hardman, whose name occurs in this controversy, is not now with us to take his share therein, but I feel convinced he would have concurred in what I have written.

EDward HulL.

Geological Survey Office, Dublin, 7th Oct. 1887.

\title{
OPITUARY. \\ JOHN EDWARD LEE, F.S.A., F.G.S., ETC.
}

Born December 21st, 1808; Died August 18th, 1887.

Devonshine has lost another excellent geologist and antiquary in Mr. John Edward Lee, of Villa Syracusa, Torquay. Mr. Lee was born at Newland, Hull, Dec. 21st, 1808. His father having died when be was very young, he was brought up by two uncles, Avison and John Terry, and at sixteen he entered their shipping office in Hull. From the earliest period of his life he took an interest in science, beginning with Fntomology, and while living

1 Prof. Sollas's paper was published in the Amals and Magazine of Natural History for February, 1881. 
at Hull he took an active part in the Royal Institution there; frequently at the end of the day's work, he would shut himself in the Museum, and stay far into the night arranging the specimens it contained.

His health failing, he travelled abroad, first in Norway and Sweden, afterwards in Russia and other parts of the continent. During these tours he sketched, and also mastered French and German thoroughly.

In 1841 he entered the Iron Works (J. J. Cordes \& Co.) of Newport, Monmouthshire, where be spent the best years of his life.

In 1846 he married Miss Gravely, of Torquay, and they resided at the Priory, Caerleon, till 1868, when anxiety for Mrs. Lee's health decided his removal to Villa Syracusa, Torquay; but he still constantly went back to Monmouthshire for many years.

During all the years of his residence at Caerleon, and later at Torquay, until failing health compelled him to abandon many of his cherished pursuits in life, he worked steadily and uninterruptedly at various branches of science, principally at Geology and Archæology.

He was one of the founders of the Monmouthshire and Caerleon Antiquarian Society, to the Proceedings of which he frequently contributed. He also aided in the formation of the Museum at Caerleon, publishing, under the title of "Isca Silurum," an illustrated catalogue of the Roman remains discovered at Caerleon, the ancient capital of the "Silures."

He exchanged fossils with geologists in all parts of the world, and carried on a large correspondence with many foreigners, who had either visited his collection at Caerleon or Torquay, or whom he had met during his numerous continental travels, or others in America and elsewhere with whom he had no personal acquaintance. All his journeys were undertaken with a scientific object, and he was in the habit of carrying small sketch-books with him when travelling, the contents of which he utilized in his publications, many of his sketches appearing in "The Note-Book of an Amateur Geologist," published in 1881 .

His principal work was a translation and revision (assisted by the author) of Dr. Keller's Lake Dwellings of Switzerland, printed in 1866 , and a second edition (in two volumes) in 1878; all the plates for this work, 206 in number, were drawn by Mr. Lee for the English edition, and illustrate more than two thousand five hundred objects, obtained from between two and three thousand separate lakedwellings." Mr. Lee's other works are, " Roman Imperial Photographs" and "Roman Imperial Profiles" (the latter being a series of more than 160 lithographic profiles enlarged from coins), both published in 1874 .

A translation of Conrad Merck's Fxcavations at the Kesslerloch, near 'Thayingen, Switzerland, a cave of the Reindeer period, followed in 1876; and an English version of Prof. Roemer's Bone-cave of Ojcow in Poland in 1884.

One of Mr. Lee's most interesting geological expeditions was made to Italy in 1868, in company with one of his earliest friends, Prof. John Plillips of Oxford, to study the phenomena of Vesuvius, then in active eruption. 
Ten years later (1878) the writer of this notice had the pleasure to accompany Mr. Lee to the Eifel district, where, being happily ioined by Prof. Ferdinand Roemer, of Breslau, the historian of the Deronian rocks of this region, a delightful fortnight was spent in collecting the fossils of Gerolstein, Prüm, and other localities.

Mr. Lee contributed several important papers to the Grocogical Magazine on points in Devonian geology which he had worked out; he was the original discoverer of many fossils described by the late Mr. J. W. Salter, F.G.S. (as Homalonotus Johannis, etc.)

He gave his most valuable and extensive collection, contained in 31 cabinets and comprising upwards of 21,000 specimens, to the British Museum (Natural History), in 1885. This collection not only embraces a large series of British fossils from all formations, many of which have been figured and described, but a most valuable and instructive collection from almost every important European locality where fossils abound.

Althongh his bodily powers began of late years to fail, his intellect remained bright, especially on all matters of science, to the last, and after be failed to write. he dictated and signed many letters, giving clear and accurate scientific information to correspondents, and he was full of plans and ideas for the furtherance of science up to the end.

Mr. Lee was a Member of the British Association, a Fellow of the Society of Antiquaries, and a Fellow of the Geological Society of London.

\section{SIR WILLIAM VERNON GUISE, BART., F.L.S., F.G.S.} Born 1816, Died 1887.

Sir William Guise was the eldest son of the late Gen. Sir John Wright Guise, Bart., one of the most distinguished Peninsula officers, by his marriage with Charlotte Diana, daughter of the late John Vernon, Esq., of Clontarf Castle, County Dublin. He was born in the year 1816, and succeeded to his father's title in 1865 . He was a Magistrate and Deputy-Lieutenant for Gloucestershire, and served as High Sheriff of that county in 1872 . He was also a retired Lieutenant-Colonel of the Royal South Gloncestershire Militia. Sir William married in 1844, Margaret Anna Maria, daughter of the Rev. D. H. Lee-Warner, of Walsingham Abbey. He is succeeded by his eldest surviving son, William Francis George, who was born in 1851 .

Sir William Guise was elected a Fellow of the Geological Society in 1841; and although not a founder, was for many years one of the most active members of the Cotteswold Naturalists' Field Club. Only last year he retired from the office of President, which he had held for 28 years. He had a wide general knowledge of Geology, Conchology, Botany, and Archæology, and there were few objects or places of in terest in Gloucestersbire with which he was not acquainted: thus he was eminently qualified to direct the Excursions of the Club, while his hearty and genial manners contributed much to the enjoyment of the meetings. Sir William Guise died on the 24th September, at his residence, Elmore Court, near Gloncester. 